to recognise "...the right of everyone to the enjoyment of the highest attainable standard of physical and mental health." Available from: http://www.ohchr.org/EN/Professionallnterest/Pages/CESCR.aspx

\section{References}

1. Dutta A, Barker C, Kallarakal A. The HIV treatment gap: estimates of the financial resources needed versus available for scale-up of antiretroviral therapy in 97 countries from 2015 to 2020. PLoS Med. 2015 Nov 24 [cited 2017 Oct 31];12(11):e1001907; discussion e1001907. doi: 10.1371/journal.pmed.1001907. eCollection 2015 Nov. Available from: http://journals.plos.org/plosmedicine/article?id=10.1371/journal. pmed.1001907

2. Ministry of Law and Justice, Government of India. The Human Immunodeficiency Virus and Acquired Immune Deficiency Syndrome (Prevention and Control) Act, 2017 New Delhi: MoLJ; 2017[cited 2017 Oct 24]. Available from: http://naco.gov.in/hivaids-act-2017

3. The Lawyers Collective. Legislating an epidemic: HIV/AIDS in India. New Delhi:Universal Law Publishing; 2007.

4. World Health Organisation, Joint United Nations Programme on HIV/AIDS. Guidance Note. Reduction of HIV-related Stigma and Discrimination, 2014. Geneva: UNAIDS; 2014 [cited 2017 Oct 24]. Available from: http://www.unaids.org/sites/default/files/media_ asset/2014unaidsguidancenote_stigma_en.pdf

5. Ministry of Law and Justice, Government of India. Section 18(2), Mental Healthcare Act, 2017, Section 18(2). New Delhi: MoLJ; 2017 [cited 2017 Oct 24]. Available from: http://www.prsindia.org/uploads/media/ Mental\%20Health/Mental\%20Healthcare\%20Act,\%202017.pdf

6. Medical Council of India, Code of Ethics Regulations, 2002 [cited 2017 Oct 24] Available from: https://www.mciindia.org/ActivitiWebClient/ rulesnregulations/codeofMedicalEthicsRegulations2002

7. Justice KS Puttaswamy (Retd.) v Union of India, Supreme Court of
India, Writ Petition (Civil) No. 494 of 2012. Available from: http:// supremecourtofindia.nic.in/supremecourt/2012/35071/35071_2012_ Judgement_24-Aug-2017.pdf

8. Cameron E, Burris S, Clayton M. HIV is a virus, not a crime: ten reasons against criminal statutes and criminal prosecutions. J Int AIDS Soc. 2008 Dec 1 [cited 2017 Oct 24];11:7. doi: 10.1186/1758-2652-11-7. Available from: https://www.ncbi.nlm.nih.gov/pmc/articles/PMC2635346/

9. Global Commission on HIV and the Law. Risks, rights and health, 2012 [cited 2017 Oct 24]:p.24. Available from: https://hivlawcommission.org/ wp-content/uploads/2017/06/FinalReport-RisksRightsHealth-EN.pdf

10. Government of India. Indian Penal Code, 1860 [cited 2017 Oct 24]. Available from: https://india.gov.in/indian-penal-code-act-1860

11. Dreze J. Dissent and Aadhaar. The Indian Express, May 8, 2017 [cited 2017 Oct 24]. Available from: http://indianexpress.com/article/opinion/ columns/dissent-and-aadhaar-4645231/

12. Human Rights Watch. Epidemic of Abuse - Police Harassment of HIV/ AIDS Outreach Workers in India. New York: Vol. 14, No. 5 (C); July 2002 [cited 2017 Oct 24]. Available from: https://www.hrw.org/reports/2002/ india2/india0602.pdf

13. US Department of Health and Human Services. Guidelines for the use of antiretroviral agents in adults and adolescents living with HIV; 2015 [cited 2017 Oct 24]. Available from: https://aidsinfo.nih.gov/guidelines/ html/1/adult-and-adolescent-arv-guidelines/18/discontinuation-orinterruption-of-antiretroviral-therapy

14. US Centers for Disease Control and Prevention. HIV Treatment as Prevention [cited 2017 Oct 24]. Available from: https://www.cdc.gov/ hiv/risk/art/

15. Parliament clears landmark HIV Bill. The Hindu. 2017 April 11 [cited 2017 Oct 24]. Available from: http://www.thehindu.com/news/national/ parliament-clears-landmark-hiv-bill/article17930015.ece

\title{
Medical ethics in times of conflict - why silence is not an option
}

\section{JOHN CHISHOLM, JULIAN SHEATHER}

\section{Abstract}

In this commentary we argue that medical ethics has a key role in discussing the effects of conflicts and other violent human rights abuses. Contemporary medical ethics is an emerging academic discipline without clearly defined boundaries and we have no desire to impose them. We are seeking instead to indicate the kinds of issues that naturally and ordinarily arise within its purview. Recent history has seen a closer relationship and interdependency between medicine and the state. This has led, at times, to tension between professional obligations and state interests. Many would prefer medical ethics to step aside from sectarian politics and focus on the doctor-patient relationship and the objective and neutral medical sciences that underpin

\footnotetext{
Author: John Chisholm (john.chisholm@john-chisholm.demon.co.uk), Chair, Medical Ethics Committee, British Medical Association; Julian Sheather (corresponding author - JSheather@bma.org.uk), Specialist Adviser, Ethics and Human Rights, British Medical Association, UK.

To cite: Chisholm J, Sheather J. Medical ethics in times of conflict - why silence is not an option. Indian J Med Ethics. 2018 Jan-Mar;3(1). NS: 39-42. DOI: 10.20529/IJME.2017.095.

Published online on November 7, 2017.

Manuscript Editor: Sunita VS Bandewar

OIndian Journal of Medical Ethics 2017
}

it. However, given the role that social inequities play in health outcomes, doctors have been obliged to speak out against such inequities or even against state practices which directly contribute to poor health. For those committed to the impartial practice of medicine, and to the promotion of human wellbeing, silence during times of conflict is seldom an option.

\section{Introduction - politicising medicine}

In her foreword to the British Medical Association's (BMA) handbook on medicine and human rights, Dr Wendy Orr, a former District Surgeon in Port Elizabeth in South Africa, writes with great force about working with detainees during the apartheid regime (1). She describes how, as a young doctor, she became aware of the systematic abuse of detainees by the security forces and the silence, complicity and evasiveness of her medical colleagues. She recounts her disbelief and growing moral disorientation as she realised she was expected to declare patients "fit" for punishment, to provide medical witness to regular canings and to turn a blind eye to torture and other forms of physical abuse. Dr Orr's moving testimony is, sadly, only one example in the handbook of the many ways in which the provision of healthcare has been compromised by state pressures during times of conflict and tension. Other conflicts cited include the Balkan wars of the 1990s where health professionals were targeted and killed for treating 
enemy combatants; the targeting of patients in hospital premises in Sierra Leone and Chechnya in 1999-2000; and the arrest and incarceration of doctors in Turkey for providing treatment to patients connected to Kurdish dissidents. To some degree, the BMA's interest in this area was sharpened by doctors raising concerns about the mistreatment of detainees during the Northern Irish "troubles" in the 1970s. More recently, the BMA has spoken out about the almost entire collapse of medical neutrality during recent conflicts, particularly, although not exclusively, in the Greater Middle East (2). These conflicts have been characterised by complete contempt for the Geneva Conventions and their Protocols and International Humanitarian Law (3), with medical professionals and healthcare facilities systematically targeted by combatants.

\section{Politics and medical ethics}

There has been recent debate in this journal about whether it is appropriate for a publication dedicated to medical ethics to consider ethical concerns and abuses of human rights arising during conflicts (4). In response to a paper on the use of pellet guns for crowd control, some commentators argued that the political origin of their use put such matters beyond the reach of medical ethics (5). One commentator suggested the journal should restrict itself to "analysing the basic pathology, symptoms, treatment and ethics related to the diagnostics and the treatment." (6)

We do not want to comment on specific issues, the publication of individual papers, or the editorial policies of the IJME. Behind the criticisms of the journal can perhaps be felt a desire for medicine and its allied disciplines, such as medical ethics, to step aside from the fog of sectarian politics and focus on the doctor-patient relationship, and the objective and neutral medical sciences that underpin it. Medicine, in this construction, is, at its therapeutic heart, an apolitical enterprise.

Such a view may be understandable. The difficulty is that, sadly, political circumstances seldom show respect for it. The experience of the BMA over the last thirty years suggests not that medical ethics has sought to expand into politics; but that, repeatedly, politics has intruded into medicine, seeking to displace it from its proper goals, in pursuit of the interests of vested powers or specific political agendas. In turn, the response from sectors of the medical profession has been rooted in its core ethical obligations: to put the best interests of patients first.

\section{What is medical ethics?}

Before we go on to look at some of the areas in which these issues have arisen, it might be worth asking, in a general sense, what we mean by medical ethics. Contemporary medical ethics is an emerging academic discipline without clearly defined boundaries, and we have no desire to impose them. We are seeking instead to indicate the kinds of issues that naturally and ordinarily arise within its purview.

Our interest in medical ethics has arisen partly through our involvement with the BMA - a British trade union and professional association for doctors - and its ethics committee and ethics and human rights department. As a representative association of doctors in the UK, the BMA both responds to, and tries in some ways to anticipate, the ethical challenges that its members are or will be facing. To this extent, our understanding of the field of medical ethics is shaped by the experiences and professional needs of doctors working both in the UK and overseas, by the ethical issues they encounter and the advice they seek.

Although medical ethics is now an academic discipline, from a medical perspective, there is a very old duty-based ethical tradition internal to medical practice that reaches back at least as far as the ancient Greek Hippocrates (460-377 BC). The Hippocratic tradition - which we separate out to an extent from the Hippocratic Oath that contains much that is extraneous and irrelevant to medicine - sets out, among other things, a minimal set of duties, or professional requirements, that all doctors are expected to fulfil in their professional relationships with patients. These duties, exercised over time, became internalised as core medical virtues and have been at the centre of professional ethics for several millennia.

More recently, the practice of medicine has been subject to several transformations that have brought with them unprecedented ethical challenges. One is the exponential increase in the sophistication and reach of medical technology. From genetic manipulation to in-vitro fertilisation and enormous advances in life-saving treatment, medicine has given rise to moral challenges of huge social significance that medicine itself, and the Hippocratic tradition, have not had the resources to respond to. Instead medicine has formed a fertile relationship with other disciplines, such as moral philosophy and medical law, to seek philosophically coherent and socially and legally acceptable responses to these questions.

Secondly, and perhaps more importantly for our purposes, there has been an enormous growth in the reach and responsibilities of the modern state over the last century and a half, particularly in economically more developed countries. To speak from a UK perspective, the last century has seen the state take over responsibility for the provision of health, social care, education and, until recent reforms, major utilities to the populations over which it is sovereign. Among its many consequences has been a much closer relationship and interdependency between medicine and the state. This has led, at times, to tension between professional obligations and state interests. From the BMA's perspective, areas of sharp ethical concern have included the delivery of healthcare in detention settings - where there is a real risk of medicine being co-opted into and sometimes subordinated to the disciplinary needs of institutions - the role of doctors in the armed forces, where core moral obligations, such as medical impartiality, can come into tension with military necessity, and the involvement of doctors in assessing the eligibility of individuals with disabilities to state benefits (7). Although not specifically relevant in the UK context, other areas of moral tension in this area include the role of doctors in relation to 
capital punishment, torture and corporal punishment; the extent to which medical knowledge and skills - and even the medical records of individual detainees - should be involved in the development of interrogation techniques; and whether medical knowledge of the human body should be made available for the development of modern weapons.

Finally, as scientific understanding of the origins of poor health increases, so medicine has turned its attention "upstream", to the remediable causes of ill health. This has meant looking at a wide range of factors that contribute to poor health. Interest has spread beyond traditional public health concerns such as disease vectors, clean water and sanitation. It now includes the built environment, individual lifestyle choices, the impact of powerful commercial organisations, such as food and drink manufacturers and the tobacco industry on personal choices that affect health, as well as the social determinants of health - the role social inequalities play in health outcomes - and the impact of conflict on individual and public health. Given that effective change in many of these areas involves state intervention, public health medicine has increasingly to engage with irreducibly political questions: to what extent, for example, and for what purposes, is the state justified in interfering with private choices?

\section{Medical ethics and the World Medical Association}

There is a risk that the experience - and perspective - of the BMA may be seen, to some degree, as localised, specific to a nation or region and therefore not generalisable. The BMA, like the Indian Medical Association, is an active member of the World Medical Association (WMA). The WMA currently has 111 national medical association members from all continents, and can therefore reasonably be considered representative of the concerns of the medical profession globally. On its website, the WMA describes one of its main objectives as working "for the highest possible standards of ethical behaviour and care by physicians." (8) In support of this goal, the WMA has developed a comprehensive list of statements and declarations that address areas of ethical concern to the global medical profession. There is insufficient space to list all the resolutions here - they are readily available on the WMA website (9) - but their range is noticeable: they spread across the areas that we have described above (such as torture and hunger-strikes) and are in no way limited to "analysing the basic pathology, symptoms, treatment and ethics related to the diagnostics and the treatment." In relation specifically to social unrest, in 2015 the WMA issued a statement on riot control agents, stating:

The WMA recognises that the inappropriate use of riot control agents risks the lives of those targeted and exposes people around, amounting to a potential breach of human rights standards, in particular the right to life, the right to freedom of expression and of peaceful assembly as stated in the Universal Declaration of Human Rights (10)

The statement clearly recognises a role for the medical profession in speaking out against state practices that may both be seriously prejudicial to health and violate core human rights, including the right to life. In relation to weapons, including firearms, in 2016 the WMA issued a revision of its statement on weapons of warfare and their relation to life and health.

The WMA believes that the development, manufacture and sale of weapons for use against human beings are abhorrent. To support the prevention and reduction of weapons injuries, the WMA:

- Supports international efforts to define objective criteria to measure the effects of current and future weapons, which could be used to stop the development, manufacture, sale and use of those weapons;

- Calls on National Medical Associations to urge national governments to cooperate with the collection of such data as are necessary for establishing objective criteria;

- Calls on National Medical Associations to support and encourage research into the global public health effects of weapons use, and to publicise the results of that research, both nationally and internationally. This will ensure that both governments and the public are aware of the long-term health consequences of weapons use on noncombatant individuals and populations (11).

Given the impact of weapons on human bodies and minds, and the medical involvement in responding to the injuries - and the importance of research into the impact of modern weapons on human bodies; and into the appropriate management of wounds - there is an unambiguous role for the medical profession. To the extent that the WMA seeks to guide the global medical profession in relation to professional standards, it would be surprising if a journal of medical ethics were unable or unwilling to comment freely on issues such as these.

\section{Medical neutrality and times of conflict}

We have seen how large-scale changes in medicine and the relationship between medicine and the state have presented the medical profession with far-reaching ethical challenges in recent decades. In responding, the profession has consistently emphasised the principle of medical neutrality. Medical neutrality is at the humanitarian core of medicine. It seeks to forge a moral space in which doctors can focus exclusively on health and the health needs of patients. The principle faces two ways. It demands respect for the ability of doctors and other health professionals to provide appropriate care and treatment to the injured and wounded without interference or fear of reprisal. It seeks, that is, to limit external interference in the proper purposes of medicine. But it also looks inward, toward health professionals, seeking to ensure that they focus on the health needs of patients. As recent conflicts have made clear, this neutral humanitarian space, this ability of health professionals to focus exclusively on the needs of their patients, remains under threat.

Given that the most serious threats to medical impartiality have come largely from state encroachment, a critical aspect 
of medical impartiality is doctors' ability to speak out about health-related aspects of conflicts. Where, for example, doctors are seeing patients who have sustained injuries as a result of state responses to civil unrest, the documentation and reporting of those injuries is a core part of the medical response. If doctors cannot speak out, if they cannot draw attention to the health-related impacts of conflicts, they risk the loss of professional independence. Paradoxically, it is the ability of doctors to speak out that best serves their neutrality. By contrast, any attempt to restrict the freedom of doctors to raise concerns threatens the principle of neutrality, risking the co-option of medical care into non-medical purposes. In our view vocal medical comment on the health impacts of conflict and of violence is a far better guarantee of the independence of the profession - and of the wellbeing of patients - than an imposed or self-imposed silence.

\section{Conclusion}

Medicine is, and has to an extent always been, a morally inflected practice. It seeks to realise certain goods essential to human flourishing. Its primary focus is on the relief of suffering and the promotion of wellbeing. It lays claim to universal values - that the value of human life, and human flourishing, transcends partisan political interests. In order to achieve its core goals, medicine needs to be able to resist pressures to divert its energies or practices toward sectarian goals. In order to achieve this there will be times when doctors need to draw attention to the health costs - and the costs in human suffering - of those conflicts. For those committed to the impartial practice of medicine, and to the promotion of human wellbeing, silence during times of conflict is seldom an option. Doctors, individually and collectively, have a moral duty to speak out about threats to and abuses of human rights.

\section{References}

1. British Medical Association (2001). The Medical Profession and Human Rights: Handbook for a changing agenda. London: BMA.

2. Sheather J, Hawkins V. Even in war there are moral boundaries-they must be strengthened. BMJ.2016;355:i6464.

3. United Nations Security Council. Resolution 2286. Protection of civilians in armed conflict. 2016 May 3 [cited 2017 Jul 26]. Available from: http:// unscr.com/en/resolutions/doc/2286.

4. David S. Use of pellet guns for crowd control in Kashmir: how lethal is non-lethal? Indian J Med Ethics. 2017 Apr-Jun;2(2)NS:124 -7. DOI: 10.20529/IJME.2017.029. Available from: http://ijme.in/articles/ use-of-pellet-guns-for-crowd-control-in-kashmir-how-lethal-is-nonlethal/?galley=html

5. Ghooi RB. Should a medical ethics journal discuss the actions of the security forces? Indian J Med Ethics. 2017 Apr-Jun;2(2)NS:127-8. DOI:10.20529/IJME.2017.030. Available from: http://ijme.in/articles/ should-a-medical-ethics-journal-discuss-the-actions-of-the-securityforces/?galley=html

6. Magotra R. Response to David's article on the use of pellet guns in Kashmir. Indian J Med Ethics. 2017 Jul-Sep;2(3) NS:217. DOI:10.20529/ IJME.2017.060. Available from: https://ijme.in/articles/response-todavids-article-on-the-use-of-pellet-guns-in-kashmir/?galley=html

7. Dual Loyalty and Human Rights in Health Professional Practice: Proposed Guidelines and Institutional Mechanisms: A Project of the International Dual Loyalty Working Group. Cape Town: Physicians for Human Rights and University of Cape Town, 2002.

8. World Medical Association. Medical Ethics. Deontology, Codes of Practice, Guidelines, Professionalism. Date unknown [cited 2017 Jul 4]. Available from: https://www.wma.net/what-we-do/medical-ethics/.

9. World Medical Association website. Date unknown [cited 2017 Jul 4].Available from: https://www.wma.net/.

10. WMA Statement on Riot Control Agents. 2015 Oct 16 [cited 2017 Jul 4]. Available from: https://www.wma.net/policies-post/wma-statementon-riot-control-agents/. Accessed 04 Jul. 17.

11. WMA Statement on Weapons of Warfare and their Relation to Life and Health. 2006 Oct 12 [cited 2017 Jul 4]. Available from: https://www.wma. net/policies-post/wma-statement-on-weapons-of-warfare-and-theirrelation-to-life-and-health/.

\section{Be a part of IJME}

IJME invites readers to submit research studies, comments, case studies, reports, reviews, letters, as also poems, short stories, original paintings and photographs of print quality ( both in colour and B/W) to be considered for publication.

All submitted matter is subject to peer review.

Contributors are neither paid nor charged any fee for published matter. 